\title{
ANALISIS KONDISI RUMAH SEKITAR RUMAH PENDERITA LEPTOSPIROSIS DI KOTA SURABAYA TAHUN 2018 (DiKelurahan Babatan, Kecamatan Wiyung, Kota Surabaya, Jawa Timur)
}

Nadia Putri Ramadhan', Umi Rahayu, Imam Thohari

\begin{abstract}
ABSTRAK
Rumah yang sehat dibutuhkan agar fungsi dan kegunaan rumah dapat terpenuhi dengan baik salah satunya adalah melindungi penghuninya dari gangguan penyakit menular. Leptospirosis termasuk salah satu penyakit menular zoonosis disebabkan oleh Leptospira interogans, golongan spirochaeta yang dapat ditularkan dari hewan ke manusia. Tujuan dari penelitian ini adalah mengetahui bagaimana kondisi rumah di sekitar rumah penderita leptospirosis di Kelurahan Babatan, Kecamatan Wiyung, Kota Surabaya, Jawa Timur Tahun 2018.

Hasil penelitian menunjukkan terdapat $76(96 \%)$ rumah yang kondisi dalam rumahnya memenuhi syarat dan sisanya $3(4 \%)$ rumah yang tidak memenuhi syarat. ketiga variabel lainnya yaitu yaitu kondisi lingkungan luar rumah, keberadaan tikus, dan keberadaan hewan peliharaan menunjukkan hasil yang memenuhi syarat $45(57 \%)$ rumah dan yang tidak memenuhi syarat $34(43 \%)$ rumah; $54(68 \%)$ rumah memenuhi syarat dan yang tidak memenuhi syarat 25 (32\%) rumah; 75 (95\%) rumah memenuhi syarat dan yang tidak memenuhi syarat $4(5 \%)$ rumah.
\end{abstract}

Kata Kunci : Kondisi Rumah, Leptospirosis.

\section{A. PENDAHULUAN}

Pengertian

rumah

menurut Kepmenkes RI Nomor :

829/MENKES/SK/VII/1999

tentang Persyaratan Kesehatan

Perumahan, rumah merupakan

salah satu kebutuhan dasar

manusia yang berfungsi sebagai

tempat tinggal atau hunian yang

digunakan untuk berlindung dari gangguan iklim dan makhluk

hidup lainnya, serta tempat pengembangan kehidupan keluarga.

Dari pengertian tersebut, dapat disimpulkan bahwa rumah adalah salah satu kebutuhan dasar manusia yang dapat berfungsi sebagai hunian yang digunakan untuk tempat 
pengembangan kehidupan keluarga serta sebagai tempat berlindung dari gangguan iklim, gangguan makhluk hidup, gangguan bencana dan penyakit menular. Oleh karena itu keberadaan rumah sehat dibutuhkan agar fungsi dan kegunaan rumah dapat terpenuhi dengan baik salah satunya adalah melindungi penghuninya dari gangguan penyakit menular. Leptospirosis termasuk salah satu penyakit menular zoonosis disebabkan oleh Leptospira interogans, golongan spirochaeta yang dapat ditularkan dari hewan ke manusia. (Soedarto,2009) Menurut Data dan Informasi Profil Kesehatan Indonesia 2016, di Jawa Timur kasus leptospirosis dari periode tahun 2014-2016 mengalami fluktuaktif, yaitu pada tahun 2014 ditemukan 61 kasus dengan 2 meninggal dan angka kematian (Case Fatality Rate/CFR) sebesar 3,28\%. Angka tersebut menurun pada tahun berikutnya, jumlah kasus yang ditemukan turun menjadi 3 kasus dengan tidak ada jumlah korban meninggal sehingga angka kematian (Case Fatality Rate/CFR) pun juga nol persen. Namun, pada tahun 2016, angka tersebut mengalami kenaikan. Jumlah kasus yang ditemukan meningkat menjadi 102 kasus dengan jumlah meninggal 6 orang dan angka kematian (Case Fatality Rate/CFR) sebesar 5,88\%.

Pada saat survei pendahuluan yang didapatkan melalui data sekunder, di lingkungan RW III, kondisi rumah penderita leptopirosis yang berada di RT 10 RW III ini termasuk rumah yang belum memenuhi persyaratan rumah sehat seperti kondisi lantai yang masih berbentuk tanah, kondisi dalam rumah yang kotor, dan banyak ditemukan tikus di dalam rumah penderita.

Tujuan dari penelitian ini adalah mengetahui bagaimana kondisi rumah di sekitar rumah 
penderita leptospirosis di

Kelurahan Babatan, Kecamatan

Wiyung, Kota Surabaya, Jawa

Timur Tahun 2018.

\section{B. METODE PENELITIAN}

Jenis penelitian ini termasuk penelitian deskriptif. Penelitian ini menggambarkan kondisi rumah sekitar rumah penderita leptospirosis.

Berdasarkan waktunya, penelitian ini merupakan penelitian cross sectional. Menurut tempatnya, penelitian ini merupakan penelitian lapangan yaitu dengan mengadakan observasi di lokasi penelitian. (Notoatmodjo, 2012)
Lokasi penelitian adalah di wilayah kerja Puskesmas Wiyung yaitu di RT 10 RW III KelurahanBabatan, Kecamatan Wiyung, Kota Surabaya, Jawa Timur.

Penentuan jumlah sampel ini menggunakan rumus besar sampel berdasar (Supardi dan Surahman, 2014) yang jumlah keseluruhan rumahnya sebanyak 98 rumah adalah 79 rumah. Sampel yang diambil adalah rumah di sekitar rumah penderita leptospirosis (termasuk rumah penderita). Rumah penderita leptospirosis sebagai titik fokus dikarenakan radius tikus dengan sarangnya dan perluasan infestasi tikus.

Tabel 1

Jumlah Responden di Kelurahan Babatan Kecamatan Wiyung Kota Surabaya Tahun 2018

\begin{tabular}{cccc}
\hline No. & Kategori & Frekuensi & Presentase \\
\hline 1. & Bukan Penderita & 78 & $99 \%$ \\
\hline 2. & Penderita & 1 & $1 \%$ \\
\hline & Jumlah & $\mathbf{7 9}$ & $\mathbf{1 0 0 \%}$ \\
\hline
\end{tabular}




\section{Tabel 2}

Jumlah Kondisi Rumah di Kelurahan Babatan Kecamatan Wiyung Kota Surabaya Tahun 2018

\begin{tabular}{|c|c|c|c|c|c|}
\hline \multirow[t]{3}{*}{ No } & \multirow[t]{3}{*}{ Kondisi Rumah } & \multicolumn{2}{|c|}{ Responden } & \multirow[t]{3}{*}{ Total } & \multirow[t]{3}{*}{ Persen } \\
\hline & & Sakit & Tidak & & \\
\hline & & & sakit & & \\
\hline \multirow[t]{2}{*}{1.} & Tidak Memenuhi & 1 & 3 & 4 & $100 \%$ \\
\hline & Syarat & $(25,0 \%)$ & $(75,0 \%)$ & & \\
\hline \multirow[t]{3}{*}{2.} & Memenuhi Syarat & 0 & 75 & 75 & $100 \%$ \\
\hline & & $(0 \%)$ & $(100 \%)$ & & \\
\hline & Total & 1 & 78 & 79 & \\
\hline
\end{tabular}

Tabel 3

Hasil Rekapitulasi Variabel Kondisi Rumah di Kelurahan Babatan Kecamatan Wiyung Kota Surabaya Tahun 2018

\begin{tabular}{|c|c|c|c|c|c|}
\hline \multirow[t]{4}{*}{ No } & \multirow[t]{4}{*}{ Kondisi Rumah } & \multicolumn{2}{|c|}{ Responden } & \multirow[t]{4}{*}{ Total } & \multirow[t]{4}{*}{ Perser } \\
\hline & & Memenuhi & Tidak & & \\
\hline & & Syarat & Memenuhi & & \\
\hline & & & Syarat & & \\
\hline \multirow[t]{2}{*}{1.} & Kondisi Dalam & 3 & 76 & 79 & $100 \%$ \\
\hline & Rumah & $(4 \%)$ & $(96,0 \%)$ & & \\
\hline \multirow[t]{2}{*}{2.} & Kondisi Lingkungan & 45 & 34 & 79 & $100 \%$ \\
\hline & Luar Rumah & $(57 \%)$ & $(43 \%)$ & & \\
\hline \multirow[t]{2}{*}{3.} & Keberadaan Tikus & 54 & 25 & 79 & 100 \\
\hline & & $(68 \%)$ & $(32 \%)$ & & \\
\hline \multirow[t]{2}{*}{4.} & Keberadaan Hewan & 75 & 4 & 79 & 100 \\
\hline & Peliharaan & $(95 \%)$ & $(5 \%)$ & & \\
\hline
\end{tabular}

Variabel bebas yang digunakan adalah kondisi rumah yang meliputi kondisi di dalam rumah, kondisi lingkungan luar rumah, keberadaan tikus, dan keberadaan hewan 
peliharaan. variabel terikatnya adalah kejadian leptospirosis.

\section{HASIL DAN PEMBAHASAN}

1. Kondisi Rumah Berdasarkan Kondisi Dalam Rumah

Dari hasil penelitian diketahui bahwa rumah responden yang tidak memenuhi syarat tersebut dikarenakan terdapat rumah yang penataan barang didalam rumahnya tidak baik, kurang rapi, dan bersih sehingga menyebabkan kondisi dalam rumah yang lembab. Responden yang memiliki luas rumah yang sempit ditambah dengan intensitas barang banyak juga menyebabkan kondisi dalam rumah penuh sehingga yang menyulitkan penghuni dalam beraktivitas. Keberadaan bahan pangan dari responden ada yang tidak memenuhi syarat, ini dikarenakan responden menyimpan bahan pangan pokok pada tempat terbuka seperti menyimpan beras tetap pada karungnya yang akan membuat tikus lebih mudah untuk mendapatkan makanannya.
Penyimpanan makanan siap saji yang tidak ditutup juga dapat mengundang tikus dan mempermudah tikus dalam menjangkau makanannya. Dalam hal adanya tempat sampah di dalam rumah, sebagian besar dari keseluruhan responden tidak memenuhi syarat karena adanya tempat sampah di dalam rumah yang baru akan dibuang ke tempat sampah luar rumah pada pagi hari. Hal tersebut dapat menyebabkan tikus berkeliaran dalam rumah untuk mencari sisa makanan (memperbesar kemungkinan untuk tikus kencing di dalam rumah).

Rusmini

(2011), mengatakan bahwa kondisi dalam rumah yang buruk dapat menjadi habitat yang aman bagi tikus, dimana tikus ini merupakan reservoar yang penting bakteri Leptospira, karena sebesar $>50 \%$ tikus dapat mengeluarkan bakteri Leptospira secara massif (terusmenerus) melalui urin selama hidupnya, tanpa menunjukkan gejala sakit.

2. Kondisi Rumah Berdasarkan Kondisi Lingkungan Luar Rumah 


\section{Dari hasil penelitian}

diketahui bahwa rumah responden yang tidak memenuhi syarat tersebut adalah karena terdapat parit di depan rumah dan tidak memenuhi syarat yaitu parit terbuka yang dapat menjadi sumber penularan penyakit leptospirosis oleh tikus jika terjadi hujan intensitas tinggi (air selokan penuh). Selain itu terdapat beberapa rumah responden yang memiliki konstruksi rumah lebih rendah/setara dengan selokan yang dapat menimbulkan genangan air/masuknya air selokan ke dalam rumah. Tidak hanya itu, sebagian besar dari responden yang masih memiliki tempat sampah diluar rumah yang tidak terbuat dari bahan kedap air dan wadah tertutup akan mengundang kehadiran vektor seperti tikus.

Hasil penelitian Agus Priyanto (2008), mengatakan bahwa kondisi selokan yang buruk akan berisiko terkena leptospirosis 3,28 kali dibandingkan dengan responden yang kondisi selokannya baik. Selain itu, Ryan
Ningsih (2010) menunjukkan bahwa keberadaan genangan air mempunyai risiko sebesar 4,1 kali terkena leptospirosis dibandingkan responden yang tidak terdapat genangan air disekitar rumahnya.

Kondisi sanitasi yang jelek seperti adanya kumpulan sampah juga dapat dijadikan indikator dari kehadiran tikus. Menurut Ryan Ningsih (2010), keberadaan sampah terutama sisa-sisa makanan yang diletakkan di tempat sampah tidak tertutup akan mengundang kehadiran tikus. Hal ini dimungkinkan tikus tersebut bisa membuang tinja serta urinnya di tempat sampah dengan adanya sampah yang berserakan menjadi sarang untuk berkumpulnya bibit penyakit.

3. Kondisi Rumah Berdasarkan Keberadaan Tikus

Dari 32 rumah yang tidak memenuhi syarat tersebut, sebagian besar pada rumah responden terdapat tikus di dalam rumah, di luar rumah, terdapat bekas gigitan tikus, terdapat lubang keluar masuk tikus, terdapat kotoran tikus, dan 
terdapat tanda-tanda lain keberadaan tikus seperti bau tikus, urine tikus, tempat hidup tikus, bangkai tikus.

Hasil penelitian oleh Niky Ria (2012), menunjukkan bahwa ada hubungan bermakna antara keberadaan tikus dengan kejadian leprospirosis ( $p$ value $=0,030$ ). Ada tikus di dalam maupun di luar rumah mempunyai risiko 10,545 kali lebih besar untuk terjadiya leptospirosis dibandingkan tidak adanya tikus.

4. Kondisi Rumah Berdasarkan Keberadaan Hewan Peliharaan Dari hasil penelitian diketahui bahwa kondisi rumah yang dinilai berdasarkan keberadaan hewan peliharaan terdapat 4 rumah (5\%) yang tidak memenuhi syarat dan 75 rumah (95\%) memenuhi syarat. Dari 4 rumah yang tidak memenuhi syarat tersebut dikarenakan responden memiliki hewan peliharaan kucing dimana letak kandangnya berada dalam satu ruangan yang dihuni.

Dalam tesis (Suratman, 2006), analisis spasial yang dilakukan terhadap faktor risiko lingkungan kepemilikan hewan peliharaan dengan kejadian leptospirosis menunjukkan bahwa 36 kasus $(59,1 \%)$ kejadian leptospirosis terjadi pada lokasi dengan kepemilikan hewan peliharaan seperti anjing, sapi, babi, kambing, dan kucing, dan atau salah satunya, sedangkan 25 kasus $\quad(40,9 \%) \quad$ kejadian leptospirosis terjadi pada lokasi dengan tidak memiliki hewan peliharaan. Hal ini berarti sebagian besar kejadian leptospirosis terjadi di lokasi dengan kepemilikan hewan peliharaan $(59,1 \%)$.

5. Kondisi Rumah Sekitar Rumah Penderita Leptospirosis

Dari hasil penelitian yang telah dilakukan, kondisi rumah kondisi rumah yang memenuhi syarat dengan kejadian leptospirosis sebanyak $0 \quad(0 \%)$ rumah, dan kondisi rumah yang tidak memenuhi syarat disertai kejadian leptospirosis sebanyak 1 $(25,0 \%)$ rumah. Untuk jumlah rumah yang kondisi rumahnya memenuhi syarat dengan responden yang tidak sakit 
sebanyak 75 (100\%) rumah dan jumlah kondisi rumah yang tidak memenuhi syarat sebanyak 3 $(75,0 \%)$ rumah. Jumlah yang menunjukkan sedikitnya kondisi rumah yang tidak memenuhi syarat ini dikarenakan sebagian besar rumah di sekitar rumah penderita ini sudah baik dan memenuhi syarat.

\section{KESIMPULAN}

4 (5\%) rumah yang tidak memenuhi syarat ini dikarenakan kondisi dalam rumahnya yang tidak memenuhi syarat (penataan barang didalam rumah yang kurang baik sehingga keleluasaan penghuni dalam beraktivitas didalam rumah terbatas, penyimpanan bahan makanan dan makanan siap saji yang tidak ditempatkan dalam wadah tertutup sehingga mudah dijangkau oleh tikus, dan terdapat tempat sampah didalam rumah), kondisi lingkungan luar yang belum memenuhi syarat (parit/selokan didepan rumah dalam keadaan terbuka dan memiliki kondisi yang kotor, memiliki tempat sampah diluar rumah yang tidak memenuhi syarat sehingga dapat dijadikan tempat perkembangbiakan oleh vektor, dan memiliki struktur rumah yang setara/lebih rendah dengan/dari parit/selokan sehingga jika terjadi hujan dapat terjadi genangan air disekitar rumah), terdapat tikus didalam maupun diluar rumah serta terdapat tanda-tanda keberadaan tikus lainnya.

\section{E. SARAN}

1. Bagi masyarakat

Membuang barang-barang didalam rumah yang sudah tidak dibutuhkan lagi, menata barang-barang didalam rumah agar tidak bersinggungan langusung dengan dinding dan lantai supaya mudah dibersihkan.

Membuang sampah yang berasal dari dalam rumah langsung pada tempat sampah yang ada diluar rumah, sehingga tidak ada tempat sampah didalam rumah.

Melakukan rat proofing yaitu dengan menutup semua lubang yang menjadi jalan masuknya tikus kedalam rumah.

2. Bagi Puskesmas Wiyung/Dinas Kesehatan Kota 
Melakukan advokasi lintas sektor seperti dinas sosial atau pihak swasta untuk menindaklanjuti kondisi rumah yang tidak memenuhi syarat.

3. Bagi peneliti lain

Dapat digunakan sebagai acuan dalam mengerjakan tugas akhir sebagai perbandingan

\section{DAFTAR PUSTAKA}

Dainanty, Niky R. Hubungan Antara Faktor Lingkungan Fisik Rumah Dan Keberadaan Tikus Dengan Kejadian Leptospirosis Di Kota Semarang. 2012: Vol. 1 No. 2 Tahun 2012

Kepmenkes No. 829/Menkes/SK/VII/1999 tentang Persyaratan Kesehatan Perumahan. Jakarta: Departemen Kesehatan RI.

Pusat Data Dan Informasi Kementerian Kesehatan RI. Kementerian Kesehatan Republik Indonesia. 2018. Data Dan Informasi Profil Kesehatan Indonesia 2016. Jakarta: Kemenkes RI

Notoatmodjo, S. 2012. Metodologi Penelitian Kesehatan. Jakarta, PT. Rineka Cipta
Ningsih, Riyan. Faktor Risiko Lingkungan Terhadap Kejadian Leptospirosis Di Jawa Tengah (Studi Kasus di Kota Semarang, Kabupaten Demak dan Pati). Program Magiter Kesehatan Lingkungan Pasca Sarjana Universitas Diponegoro Semarang, 2009.(Tesis, Belum Dipublikasikan)

Priyanto, A. Faktor-Faktor Risiko Yang Berhubungan Terhadap Kejadian Leptospirosis Studi Kasus Di Kabupaten Demak. Program Magister Epidemiologi Pasca Sarjana Universitas Diponegoro, 2008.(Tesis, Belum Dipublikasikan)

Rusmini, Bahaya Leptospirosis (Penyakit Kucing Tikus) \& Cara Pencegahannya, Gosyen Publishing, Yogyakarta. Hal 2, 3, 4, 14, 15, 59-85, 2011.

Soedarto. Penyakit Menular Di Indonesia. Jakarta: CV Sagung Seto, 2009

Supardi, S., Surahman. 2014. Metodologi Penelitian Untuk Mahasiswa Farmasi. Jakarta Timur, CV. Trans Info Media

Suratman, 2006. Analisis Faktor Risiko Lingkungan dan Perilaku yang Berpengaruh terhadap Kejadian Leptopsirosis Berat di Kota Semarang. Tesis, Program Pasca Sarjana Universitas Diponegoro Semarang. http://eprints.undip.ac.id/18703/1/S URATMAN.pdf. 31 Januari 2018 